\title{
Ki-energy (Life-energy) Stimulates Osteoblastic Cells and Inhibits the Formation of Osteoclast-like Cells in Bone Cell Culture Models
}

\author{
S. Tsuyoshi Ohnishi ${ }^{1}$, Kozo Nishino ${ }^{2}$, Satoshi Uchiyama ${ }^{3}$, Tomoko Ohnishi ${ }^{4}$ and \\ Masayoshi Yamaguchi ${ }^{3}$ \\ ${ }^{1}$ Philadelphia Biomedical Research Institute, King of Prussia, PA, USA, ${ }^{2}$ School of Nishino Breathing Method, \\ Shibuya-ku, Tokyo, ${ }^{3}$ Laboratory of Endocrinology and Molecular Metabolism, Graduate School of Nutritional \\ Sciences, University of Shizuoka, Shizuoka, Japan and ${ }^{4}$ University of Pennsylvania School of Medicine, \\ Philadelphia, PA, USA
}

Some practitioners of the Nishino Breathing Method (NBM) were found to have a higher bone density than the average values of age- and gender-matched non-practitioners. Using bone cell culture models, we investigated a possible mechanism behind this observation. For the study of bone mineralization, we performed the following two experiments using cultured osteoblastic MC3T3-E1 cells: (i) Kozo Nishino, a Japanese Ki expert, sent Ki-energy to the cells once for 5 or $10 \mathrm{~min}$ after they were seeded in culture dishes in the presence of $10 \%$ fetal bovine serum (FBS). They were incubated for $72 \mathrm{~h}$ and the cells were counted. The number in the dish with 10 -min $\mathrm{Ki}$-exposure was significantly greater than that in the control $(P<0.01$ with $n=8)$. We performed a reverse transcription-polymerase chain reaction (RT-PCR) study using these cells, but the mRNA expressions did not change significantly. (ii) After cells were incubated for $72 \mathrm{~h}$ without Ki-exposure (in the presence of FBS), they were further cultured for $48 \mathrm{~h}$ (in the absence of FBS) to promote differentiation. At the beginning of the second culture stage, $\mathrm{Ki}$ was applied once for $10 \mathrm{~min}$. After $48 \mathrm{~h}$, RT-PCR was performed. The mRNA expressions which are related to bone mineralization, such as Runx2, $\alpha 1$ (I) collagen, alkaline phosphatase and osteocalcin, increased significantly $(P<0.05$ and $n=4$ for all). For the bone resorption study, we used mouse marrow cultures, which can form osteoclast-like cells in the presence of (1-34) parathyroid hormone (PTH), and stimulate resorption. We exposed these cells to Ki-energy twice for the duration of 5 or $10 \mathrm{~min}$ on day 0 and day 4 . On day 7, the cells were counted. The number of osteoclast-like cells in dishes with Ki exposure was significantly smaller than those in control dishes $(P<0.05$ with $n=5)$. The difference between 5 -min exposure and 10 -min exposure was not statistically significant. All of our data suggest that the Ki-effect on osteoporosis should be further explored.

Keywords: bone density - bone mineralization - bone resorption - Ki energy - MC3T3-E1 cells mouse marrow culture - osteoblastic cells - osteoclast-like cells - osteoporosis - RT-PCR

For reprints and all correspondence: S. Tsuyoshi Ohnishi,

Philadelphia Biomedical Research Institute, Suite 250, 100 Ross

Road, King of Prussia, PA 19406, USA. Tel: 610-688-6276;

Fax: 610-254-9332; E-mail: stohnishi@aol.com

\section{Introduction}

Osteoporosis is a major public health problem in many countries because the aged population has been growing in recent years. Aging is known to induce a decrease in bone mass which can lead to osteoporosis (1-3).

\section{(C) 2007 The Author(s)}

This is an Open Access article distributed under the terms of the Creative Commons Attribution Non-Commercial License (http://creativecommons.org/ licenses/by-nc/2.0/uk/) which permits unrestricted non-commercial use, distribution, and reproduction in any medium, provided the original work is properly cited. 
Women are particularly vulnerable to osteoporosis because post-menopausal estrogen deficiency is linked to bone loss (4-6). Besides a pharmacological approach, such as using estrogen (6,7), bisphosphonate $(7,8)$, calcitonin $(7,9)$, calcium products $(7,10)$ and anabolic steroids (11), CAM (complementary and alternative medicine) approaches to this problem have been actively conducted. For example, nutritional products (12-16), Chinese traditional (Kampo) medicine (17) and Japanese herbal medicine (18) have been reported to have beneficial effects on osteoporosis.

In this article, we present an entirely new approach to this problem, namely, the application of Ki-energy, which can be enhanced through the practice of the Nishino Breathing Method (NBM) (19-21). This method has been taught by Kozo Nishino at two schools (Tokyo and Osaka) for the past 20 years. More than 10000 people have practiced it and various health benefits were observed (22-24). Scientific investigations on $\mathrm{Ki}$ were also conducted to demonstrate that it enhanced the immune activity of the practitioners (25), it inhibited cell division of cultured cancer cells (26) and it protected isolated mitochondria from oxidative injury (27).

One of the health benefits of NBM seems to be an increased bone density. Junko Kataoka (Professor; Japan Women's College for Physical Education), who had practiced NBM for 11 years, found that the ultrasonicwave conduction velocity (which increases with the bone density) at her ankle bone was $1586 \mathrm{~m} / \mathrm{sec}$. At her age (59 years old), the average value is $1498 \pm 24 \mathrm{~m} / \mathrm{sec}$. Her measured value corresponds to the average value for 19-year-old girls $(1556 \pm 35 \mathrm{~m} / \mathrm{sec})$ (28). Since then, several practitioners of NBM (both men and women) measured their bone density with various methods, and found that their values were $5-50 \%$ greater than the average values for the same age and the same gender (29) (See supplemental data published on the website of eCAM).

Since it is well-known that the bone density in women decreases after menopause (because of the decrease of estrogen hormones), there is a question as to why some of female practitioners, who are 50-70 years old, have a bone density greater than that of young women. Thus, we were very much interested in these observations, and decided to study Ki-effects on bone by using in vitro bone cell culture models. Our strategy was to examine whether Ki-energy could stimulate osteoblastic cells (which can increase bone formation) and/or inhibit the formation of osteoclast-like cells (which can reduce bone mass; (30)). Although our data are still descriptive, and we do not yet know the mechanism of Ki-effect on bone, we decided to present our data with the hope that our experience would stimulate interest in $\mathrm{Ki}$ study in the scientific community.

\section{Methods}

\section{Chemicals}

$\alpha$-Minimal essential medium, $(\alpha-$ MEM) and penicillin $(5000 \mathrm{U} / \mathrm{ml})$ and streptomycin $(5000 \mu \mathrm{g} / \mathrm{ml})$ were obtained from Gibco Laboratories. Fetal bovine serum (FBS) was obtained from Bioproducts, Inc. Other chemicals were of reagent grade and were obtained from Wako Pure Chemical Industries (Osaka, Japan). Water was glass distilled.

\section{Site for Experiments}

All experiments were performed at the Laboratory of Endocrinology and Molecular Metabolism, Graduate School of Nutritional Sciences, University of Shizuoka. The procedures were approved by the institutional committee of the University of Shizuoka.

\section{Application of Ki to Cell Cultures}

This is done with the same method used for our previous cancer cell study (26). An acrylic stand with a hole was prepared (Fig. 1A). In a vertical flow clean bench, an uncovered culture dish was placed on the stand and a Japanese Ki expert (K. Nishino) emitted Ki-energy to the dish for 5 or $10 \mathrm{~min}$ from his fingers (Fig. 1B). The dish

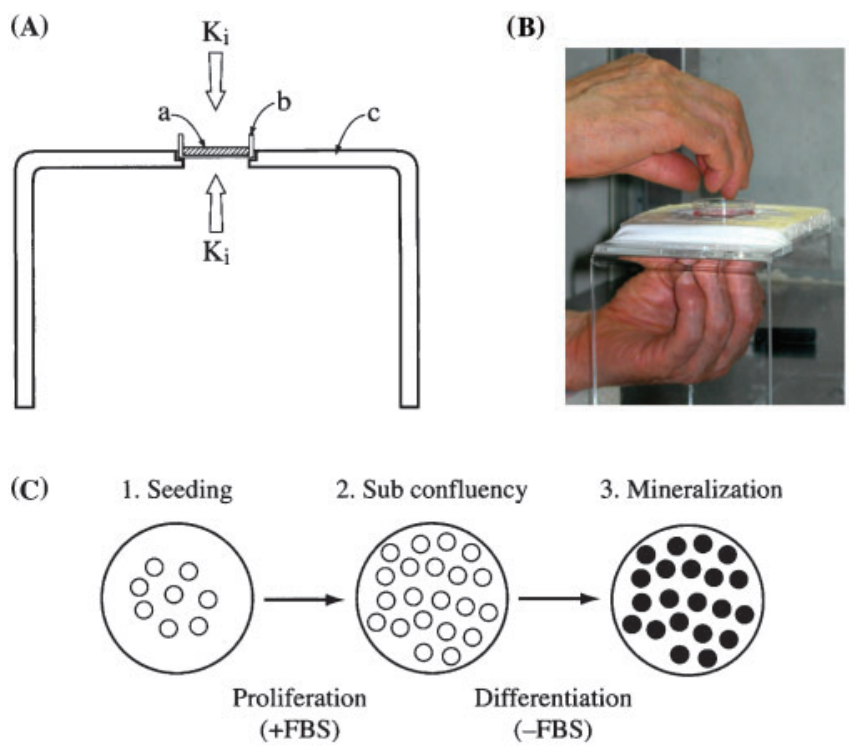

Figure 1. (A) A stand which holds a culture dish for Ki-exposure experiments. (a) bone cell culture and the medium; (b) $35 \mathrm{~mm}$ polystyrene culture dish; (c) an acrylic stand. The signs of Ki indicates that Ki-energy is applied from the fingers of a Ki-expert. (B) Photo shows how Ki-energy was applied from the fingers of Nishino inside a clean bench. (C) Schematic illustration of how osteoblastic cells were cultured. 1, Seeding of cells; 2, Proliferation in the presence of FBS until cells reach subconfluency; 3, Differentiation in the absence of FBS to reach the stage that cells can promote mineralization. 
was returned to the incubator after the $\mathrm{Ki}$-exposure for further culturing.

\section{Osteoblastic Cell Culture}

Osteoblastic MC3T3-E1 cells were cultured at $37^{\circ} \mathrm{C}$ in a $\mathrm{CO}_{2}$ incubator $(5 \%)$ in plastic dishes (polystyrene; $35 \mathrm{~mm}$ diameter) containing $\alpha$-MEM supplemented with $10 \%$ FBS (15). They were subcultured every 3 days and the cells with subconfluency were detached using $0.2 \%$ trypsin plus $0.02 \%$ EDTA in $\mathrm{Ca}^{2+} / \mathrm{Mg}^{2+}$-free phosphate-buffered saline (PBS). For the experiment (i), approximately $1 \times 10^{5}$ cells per dish were cultured for $72 \mathrm{~h}$ to obtain subconfluent monolayers in a $35-\mathrm{mm}$ plastic dish containing $2 \mathrm{ml} \alpha$-MEM with $10 \%$ FBS (Fig. 1C, 1 to 2). For experiment (ii), after the cells reached subconfluency, they were further cultured $48 \mathrm{~h}$ in the absence of FBS to promote mineralization (Fig. 1C, 2 to 3).

\section{Marrow Culture Experiments}

Bone marrow cells were isolated from male mice. Briefly: both bone ends of the femur were cut off, and the marrow cavity was flushed with $1 \mathrm{ml}$ of $\alpha$-MEM. The marrow cells, which were obtained from six animals, were washed with $\alpha$-MEM and cultured (at $2.5 \times 10^{7}$ cells $/ \mathrm{ml}$ ) in $35 \mathrm{~mm}$ dish in an incubator with a water-saturated atmosphere containing $5 \% \mathrm{CO}_{2}$ and $95 \%$ air at $37^{\circ} \mathrm{C}$. Each dish contained $2 \mathrm{ml}$ of $\alpha$-MEM, $10 \%$ heatinactivated FBS and (1-34) parathyroid hormone (PTH; $10^{-7} \mathrm{M}$ ), except for the non-PTH control. The cells were cultured for 3 days, then $0.2 \mathrm{ml}$ of the old medium was replaced with the fresh medium, and the cultures were maintained for an additional 4 days $(14,31,32)$. PTH $\left(10^{-7} \mathrm{M}\right)$ was added to the culture medium at the beginning of the culture and at the time of medium change, except for the non-PTH dishes.

\section{Enzyme Histochemistry to Detect the Formation of Osteoclast-like Cells}

After being cultured for 7 days, marrow culture cells which adhered to the dishes were stained for tartrateresistant acid phosphatase (TRACP), a marker enzyme of osteoclasts $(33,34)$. In brief: cells were washed with Hank's balanced salt solution and fixed with $10 \%$ neutralized formalin-phosphate $(\mathrm{pH} 7.2)$ for $10 \mathrm{~min}$. After the culture dishes were dried, TRACP staining was applied according to the method of Burstone (33). The fixed cells were incubated for $12 \mathrm{~min}$ at room temperature $\left(25^{\circ} \mathrm{C}\right)$ in an acetate buffer $(\mathrm{pH} 5.0)$ containing $10 \mathrm{mM}$ sodium tartrate and naphthol AS-MX phosphate (Sigma) as a substrate, and red violet LB salt (Sigma) as a stain for the reaction product.
TRACP-positive multinucleated cells (MNCs) containing three or more nuclei were counted as osteoclast-like cells.

\section{Cell Counting}

After trypsinization of the cells in each culture dish using a $\mathrm{Ca}^{2+} / \mathrm{Mg}^{2+}$-free PBS containing $0.2 \%$ trypsin and $0.02 \%$ EDTA for $2 \mathrm{~min}$ at $37^{\circ} \mathrm{C}$, cells were collected and wash-centrifuged in a PBS solution at $100 \times \mathrm{g}$ for $5 \mathrm{~min}$. The cells were resuspended in a $0.5 \mathrm{ml}$ PBS solution and an aliquot was stained with eosin. The cells were counted under a microscope using a Hemacytometer plate. For each dish, we took an average of two counts.

\section{Determination of Specific mRNA by RT-PCR}

Total RNAs were prepared as described previously (35). Osteoblastic MC3T3-E1 cells were washed three times with ice-cold PBS. Then, cells were homogenized in a buffer solution containing $4 \mathrm{M}$ guanidinium thiocyanate, $24 \mathrm{mM}$ sodium citrate $(\mathrm{pH} 7.0), 0.5 \%$ sarcosyl and isoamyl alcohol and the mixture was centrifuged at $10000 \mathrm{~g}$ for $20 \mathrm{~min}$ at $40^{\circ} \mathrm{C}$ to separate the aqueous phase from the organic phase. RNA in the aqueous phase was precipitated with isopropanol at $-20^{\circ} \mathrm{C}$. RNA precipitates were collected by centrifugation, and the pellets were redissolved in diethylpyrocarbonate-treated water.

Reverse transcription-polymerase chain reaction (RT-PCR) was performed with a Titam $^{\mathrm{TM}}$ One Tube RT-PCR kit (Roche Molecular Biochemicals) as recommended by the supplier.

Primers for amplification of mouse Runx 2 cDNA were; 5'-GTATGAGAGTAGGTGTCCCG-3' (sense strand, positions $992-1011$ of cDNA sequence) and 5'-ACATC CCCATCCATCCACTC-3' (antisense strand, positions 1156-1175) (36). The pair of oligonucleotide primers was designed to amplify a 183-bp sequence from the mRNA of mouse Runx2.

The pair of oligonucleotide primers was designed to amplify a 254-bp sequence from the mRNA of $\alpha 1$ (I) collagen. Primers for amplification of mouse alkaline phosphatase cDNA were: 5'-GATCGGGACTGGTACT CGGATAA-3' (sense strand, positions 729-751 of cDNA sequence) and 5'-CACATCAGTTCTGTTCTTCGGG TAC-3' (antisense strand, positions 860-884) (37). The pair of oligonucleotide primers was designed to amplify a 155-bp sequence from the mRNA of alkaline phosphatase.

Primers for amplication of mouse osteocalcin cDNA were: 5'-GGGGAAGGGACAACACATGA-3' (sense strand, positions 188-207 of cDNA sequence) and 5'-TCC TGGACATGGGGATTGAC-3' (antisense strand, positions 580-599) (38). The pair of oligonucleotide primers was designed to amplify a 412-bp sequence from the mRNA of osteocalcin. 
Primers for amplification of mouse TGF- $\beta 1$ cDNA were: 5'-CTCTCCACCTGCAAGACCAT-3' (sense strand, positions $633-652$ of cDNA sequence) and $5^{\prime}-\mathrm{CTGCW}$ TACAACTWAGTGA-3' (antisense strand, positions 1312-1331) (39). The pair of oligonucleotide primers were designed to amplify a $679 \mathrm{bp}$ sequence from the mRNA of mouse TGF- $\beta 1$. Primers for amplification of mouse IGF-1 cDNA were: 5'-GC AAGCTTCAGCCACCTTAC-3' (sense strand, positions 955-974 of cDNA sequence) and 5'-GGGTCGTTTACACA WAGGT-3' (antisense strand, positions 1466-1485) (40). The pair of oligonucleotide primers were designed to amplify a $511 \mathrm{bp}$ sequence from the mRNA of IGF-I.

For semiquantitative PCR, glyceroaldehyde3-phosphate dehydrogenase (G3PDH) was used as an internal standard to evaluate total RNA input. Primers for amplification of G3PDH cDNA were, 5'-GATTT GGCCGTATCGGACGC-3' (sense strand) and 5'-CTCC TTGGAGGCCATGTAGG-3' (antisense strand). The pair of oligonucleotide primers was designed to amplify a 977-bp sequence from the mRNA of rat G3PDH.

RT-PCR was performed using reaction mixture $(20 \mu \mathrm{l})$ containing 2 or $4 \mu \mathrm{g}$ of total RNAs, supplied RT-PCR buffer, Titam $^{\mathrm{TM}}$ enzyme mix (AMV and Expand ${ }^{\mathrm{TM}}$ High Fidelity), $0.2 \mathrm{mM}$ dNTP, $5 \mathrm{mM}$ dithiothreitol, $5 \mathrm{U}$ RNase inhibitor, and $0.3 \mu \mathrm{M}$ primers. Samples were incubated at $50^{\circ} \mathrm{C}$ for $30 \mathrm{~min}$, and then amplified for 30 cycles under the following conditions: denaturation for $30 \mathrm{~s} 94^{\circ} \mathrm{C}$, annealing for $30 \mathrm{~s}$ at $56^{\circ} \mathrm{C}$, and extension for $60 \mathrm{~s}$ at $68^{\circ} \mathrm{C}$. The amplified products were separated by electrophoresis on a $1.5 \%$ agarose gel and visualized by ethidium bromide staining. Image density was quantified with a FluoroImager SI (Amersham Pharmacia Biotech).

\section{Statistical Analysis}

Data were expressed as the mean $\pm \mathrm{SE}$. The significance of the difference was determined by analysis of variance with the Fisher's PLSD test for comparison of multiple groups. Calculations were done using StatView ${ }^{\text {TM }}$ software. Differences with $P<0.05$ were considered to be statistically significant.

\section{Results}

\section{Stimulation of Osteoblastic Cells by Ki-energy}

\section{Increase in cell numbers}

After MC3T3-E1 cells were seeded, Ki was applied once for 5 or $10 \mathrm{~min}$. Subsequently, they were incubated for $72 \mathrm{~h}$ in the presence of $10 \% \mathrm{FBS}$, and the cells were counted. As shown in Fig. 2, the number of Ki-exposed cells $\left(\times 10^{4}\right.$ cells/dish) increased from $39.2 \pm 1.34$ (SE) for the control to $42.0 \pm 2.13$ for 5 -min exposure and

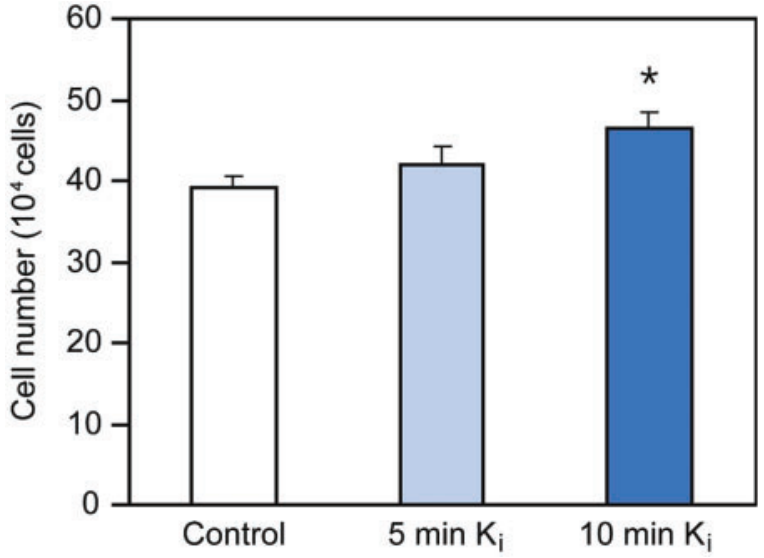

Figure 2. After osteoblastic cells (MC3T3-E1) were seeded, they were exposed to 5 or $10 \mathrm{~min} \mathrm{Ki}$-energy once, and subsequently, incubated for $72 \mathrm{~h}$ in the presence of FBS. Then, the cell number was counted. The effect of 5-min Ki-exposure was not significant. The effect of $10 \mathrm{~min}$ was statistically significant $(P<0.01$; indicated by *symbol).

$46.5 \pm 1.83$ for 10 -min exposure. The difference between the control and the 5-min experiment was not statistically significant, but that between the control and the 10-min experiment was statistically significant $(P<0.01, n=8)$.

\section{Changes in the Gene Expressions Shown in Ki-exposed Cells in the Presence and Absence of FBS}

Although the number of MC3T3-E1 cells increased with the exposure to Ki-energy, gene expressions in cells reaching subconfluent conditions did not significantly change with $\mathrm{Ki}$ as shown in Fig. 3. (In Figs. 3 and 4 , the open columns indicate experiments without Ki-exposure and the filled columns with Ki-exposure.) Therefore, we tried another experiment. We first cultured the cells for $72 \mathrm{~h}$ without $\mathrm{Ki}$-exposure in the presence of $10 \%$ FBS to bring the cells to subconfluency. After exchanging the medium with the one which did not contain FBS, Ki-energy was applied once for 5 or $10 \mathrm{~min}$, and subsequently, they were cultured for $48 \mathrm{~h}$ in the absence of FBS. We confirmed that the elimination of FBS did not cause cell death. Then, RT-PCR test was performed using these cells. We observed that Ki-exposure significantly increased gene expressions for Runx2, $\alpha 1(\mathrm{I})$ collagen, alkaline phosphatase and osteocalcin $(P<0.05 ; n=4)$. The expressions for IGF-I and TGF- $\beta 1$ did not change significantly.

\section{Inhibition of the Formation of Osteoclast-like Cells by Ki-energy}

In the presence of PTHs $\left(10^{-7} \mathrm{M}\right)$, we tested the effect of Ki-energy on mouse marrow cell cultures. Cells were exposed to Ki-energy twice for the duration of 5 or $10 \mathrm{~min}$ on day 0 and day 4 of the cell culture. On day 7 , the mouse marrow cells were stained for TRACP, 

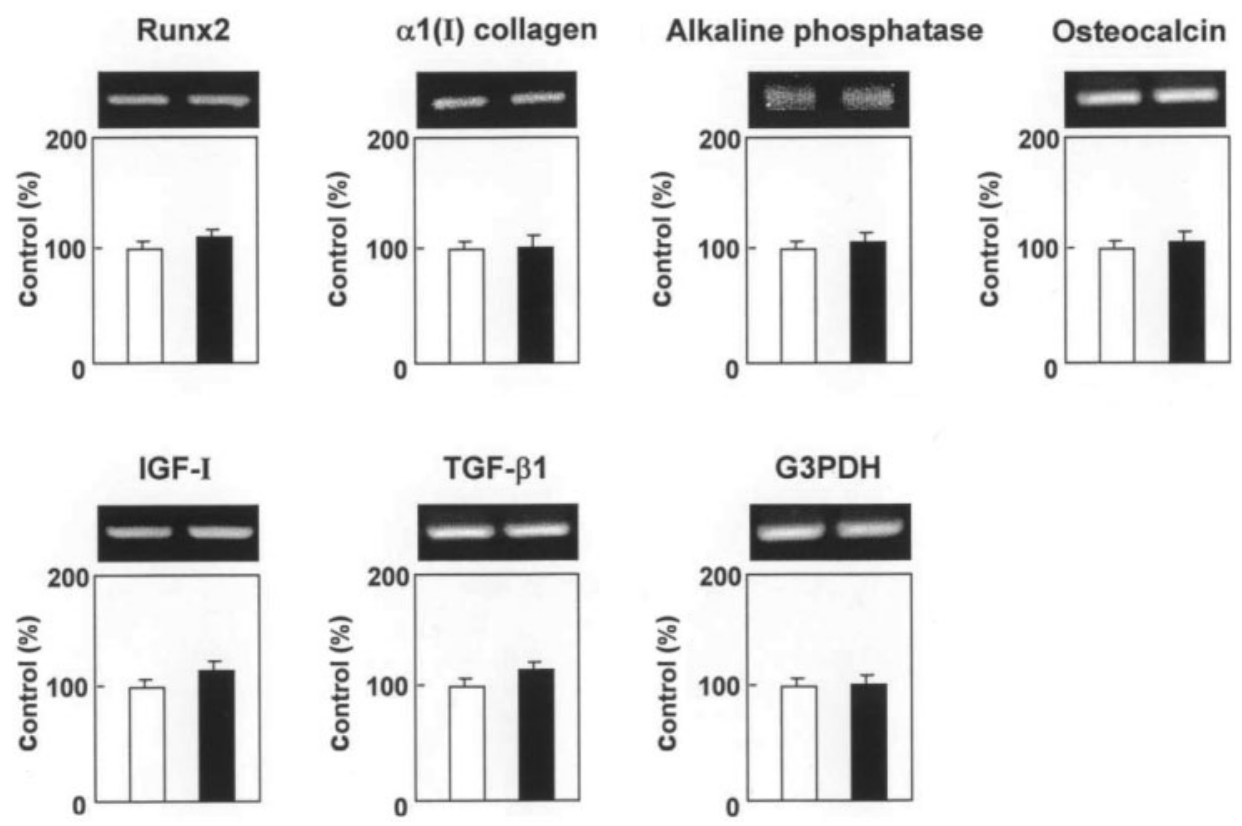

Figure 3. Changes in the mRNA expressions in MC3T3-E1 cells were measured using RT-PCR. The cells were seeded, exposed to 10 min Ki-energy once, incubated for $72 \mathrm{~h}$ in the presence of FBS, and RT-PCR was performed. The open columns are without Ki-exposure and the filled columns are with $\mathrm{Ki}$-exposure. These effects of Ki during this proliferation stage were not statistically significant. See text for details.
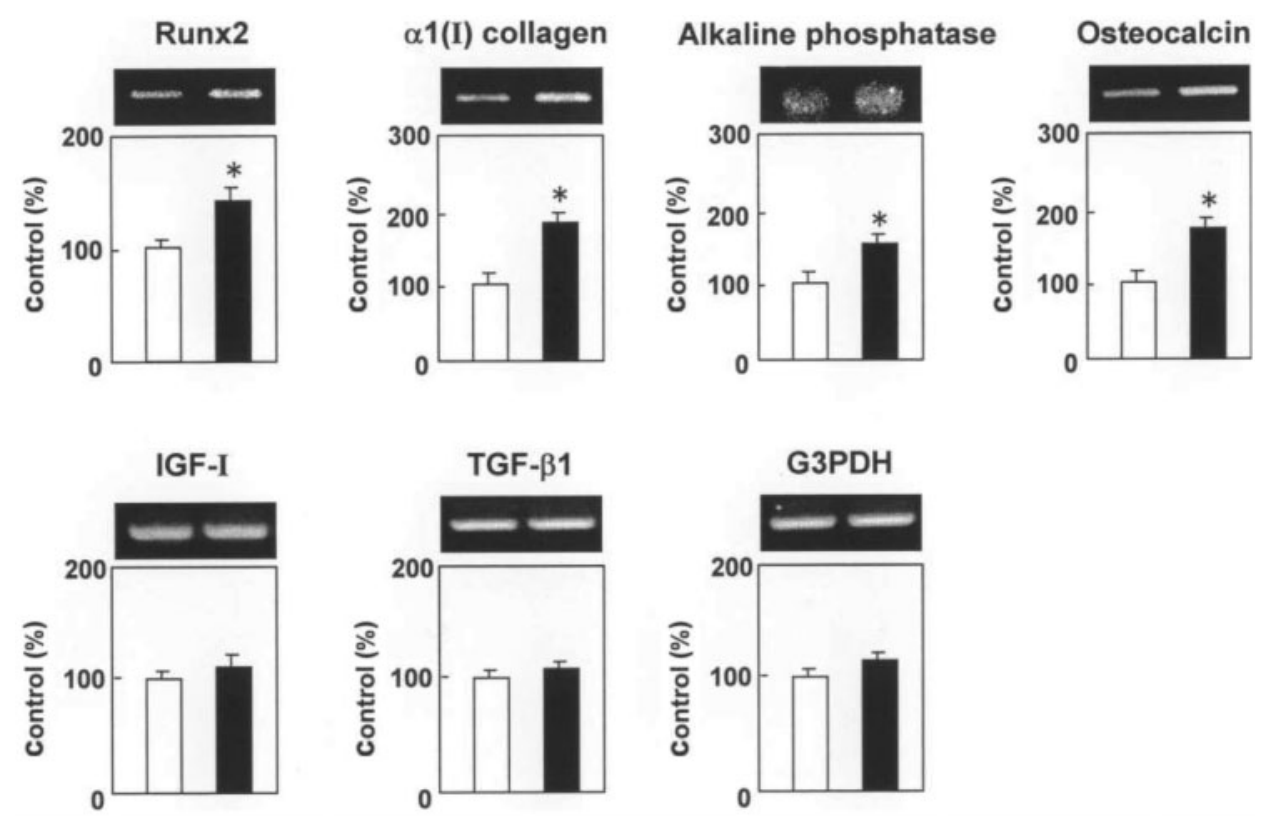

Figure 4. MC3T3-E1 cells were seeded, cultured for $72 \mathrm{~h}$ (in the presence of FBS) to reach subconfluency (no Ki-exposure). The medium was exchanged (no FBS), and cells were exposed to 10-min Ki-energy once, and cells were cultured in the absence of FBS for another $48 \mathrm{~h}$. Then, RT-PCR was performed. The open columns are without Ki-exposure and the filled columns are with Ki-exposure. The increases in mRNA expressions for RUnx2, a1(I) collagen, alkaline phosphatase and osteocalcin were all statistically significant as indicated by ${ }^{*}$ symbols $(P<0.05 ; n=4$ for each).

a marker enzyme of osteoclasts $(33,34)$. TRACP-positive MNCs (stained in a red color) were clearly decreased by the Ki-treatment (Fig. 5). The number of osteoclastlike cells were $214.3 \pm 29.4 \quad(n=5)$ (no $\mathrm{Ki}$ control), $129.6 \pm 21.2$ (with 5-min $\mathrm{Ki}$ ) and $146.8 \pm 18.3$ (with 10-min Ki). The effects of $\mathrm{Ki}$ in both 5 and 10-min exposure were statistically significant $(P<0.05, n=5$;
Fig. 6). There was no statistically significant difference between 5 and 10-min exposures.

\section{Discussion}

The idea that Ki-energy may be beneficial in osteoporosis came from the observation that the bone density of some 


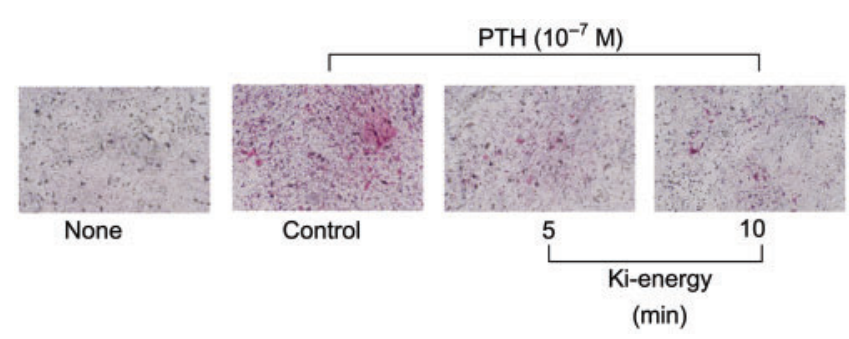

Figure 5. Histological examination of osteoclast-like cell formation. The exposure of the cells twice to Ki-energy (each time, either 5 or $10 \mathrm{~min}$ ) decreased the formation of osteoclast-like cells.

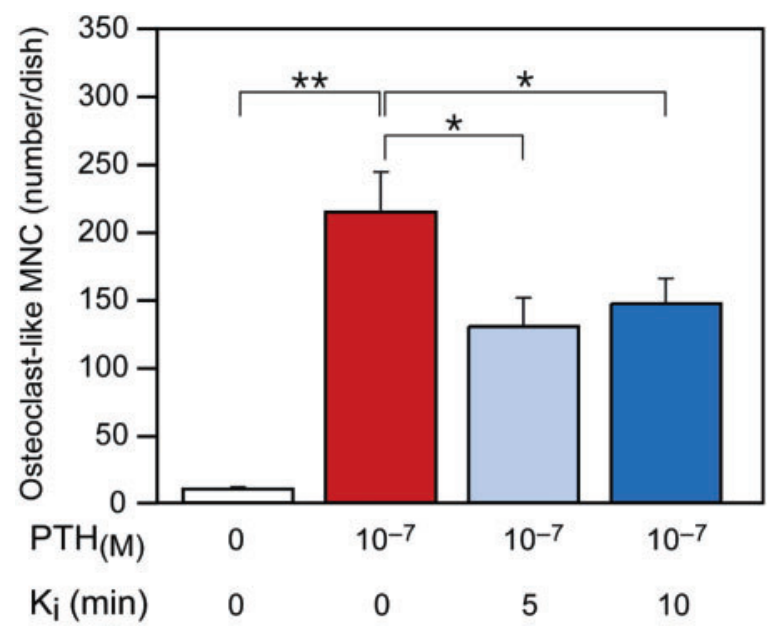

Figure 6. The cell numbers in mouse marrow cultures were counted after the cells were stained as shown in Fig. 5. Without the addition of parathyroid hormone (PTH), the cell number for osteoclast-like cells was very small (as shown in the first column from the left). With the addition of PTH $\left(10^{-7} \mathrm{M}\right)$, the number increased greatly $(P<0.01$ as shown by ${ }^{* *}$ symbol in the second column from the left). This increase of cell number was significantly inhibited by 5 or $10 \mathrm{~min}$ of $\mathrm{Ki}$-exposure $(P<0.05$ as indicated by *symbol for the 3 rd and 4th columns; $n=5$ for each). The difference between 5 and $10 \mathrm{~min}$ were not statistically significant. Ki was applied twice during the culture. See text for details.

practitioners of NBM is much higher than in age- and gender-matched non-practitioners $(24,28,29)$ (see also supplemental material on the website). In order to examine the cellular and molecular mechanisms behind this observation, we undertook this study. Using bone culture models, we analyzed whether Ki-energy emitted from the fingers of a Japanese Ki-expert (Fig. 1B) could modify the activities of osteoblastic cells and osteoclast-like cells. We first observed that a 10-min exposure to Ki-energy increased the cell number of osteoblastic cells in $72 \mathrm{~h}$ of incubation reaching the subconfluent condition (in the presence of FBS) (Fig. 2). Ki-energy stimulated a proliferation of osteoblastic cells, which suggests that Ki could promote bone formation. As shown in this figure, 5 min of Ki-exposure did not produce a significant effect. This may be because the effect is dose-related, and the change caused by 5 -min $\mathrm{Ki}$-exposure was not enough to manifest a significant effect.
As shown in Fig. 3, the gene expressions obtained from RT-PCR result did not change much with this type of experiment (exp. (i)). Therefore, we tried a different type of experiment (exp. (ii)), namely, cells were first cultured for $72 \mathrm{~h}$ without $\mathrm{Ki}$-exposure (in the presence of FBS). After the medium exchange (no FBS), Ki was applied and subsequently, the cells were cultured for $48 \mathrm{~h}$ (in the absence of FBS). In the second experiment, the mRNA expressions for the proteins related to transcription factors were significantly increased (Fig. 4). This includes the factors for the cell differentiation (Runx2), bone matrix formation $(\alpha-1$ (I) collagen), the enzyme related to calcification (alkaline phosphatase), the protein which absorbs calcium on bone surface (osteocalcin). Under this condition, the gene expressions of cytokines such as IGF-I (related to cell proliferation) and TGF- $\beta 1$ (related to bone growth factor) did not change. This suggests that the effects of Ki-energy on osteoblastic cells are not related to bone growth factors, but to the enhancement of their mineralization capacity.

The presence of FBS in the culture medium affects cellular functions. Therefore, for the analysis of signal transduction mechanism as shown earlier in this article, we always eliminate FBS from the culture medium. From a cell viability test and a DNA content assay, we confirmed that the removal of FBS did not cause cell death during the culture.

The gene expressions did not change during the proliferation stage of osteolbastic cells (Fig. 3). This suggests that the cells which are undergoing proliferation may respond to Ki-energy with a limited degree of sensitivity. For example, only cell growth was activated with $\mathrm{Ki}$ (Figs 2 and 3). On the other hand, for the cells which had completed the growing stage, Ki-energy could effectively stimulate cell functions, mainly, bone mineralization (Fig. 4).

When Ki-energy was applied to bone marrow culture, the formation of PTH-induced osteoclast-like cells was inhibited as shown by cell staining results (Fig. 5). Cell counting for the osteoclast-like cells demonstrated that Ki-exposure (twice; each time for 5 or $10 \mathrm{~min}$ ) inhibited the formation of these cells significantly $(P<0.05)$ (Fig. 6). Bone mass is determined as a dynamic equilibrium between bone formation by osteoblastic cells and bone resorption by osteoclastic cells. Therefore, our observations that Ki-energy increases the function of the former, while it decreases the function of the latter are very significant. Although we cannot directly extend the observations in culture models to in situ bone metabolism, our data suggest that Ki-energy may be beneficial in maintaining our bone mass.

Various pharmacological and nutritional means to prevent or to treat osteoporosis have been reported (6). If we were to study the effects of these methods using cell culture models, we add these compounds to the cell culture medium and incubate for few days. When we 
exchange the medium, normally, we would add the compound again. Not only the original compound, but also its metabolites would be incubated with the cells for days. Therefore, we are actually studying a kind of chronic effects of these compounds on bone formation or resorption. Compared with these methods, the mode of action of Ki-energy is entirely different. At some point during the cell culture, Ki-energy was applied once for 5 to $10 \mathrm{~min}$. In some experiments, Ki-energy was applied twice, but that is the extent of cell exposure. We are studying the effects of an acute type reaction.

Why can Ki-energy still manifest tangible changes on bone culture models? A possibility may be that 'cascade' reactions are triggered by Ki-energy. For example, suppose Ki-energy could trigger a minute increase in the activity of an enzyme a. Then, this enzyme produces the product $b$. If $b$ happened to be another enzyme, then, it produces the product $\mathrm{c}$. If this kind of chain reaction continues, then, the original change could be multiplied a million times in a short duration of time. In cells, an intricate network of signal transduction pathways, which consist of many enzymes, hormones, receptors, cytokines, DNAs and RNAs, are formed. If Ki-energy could trigger a change in the enzymatic activity located upstream of the pathways, then, it can be multiplied rapidly to create substantial changes. In the MC3T3-E1 cell culture, gene expressions related to many mineralization functions were found to be activated by Ki-energy. This would support the idea that the effect of Ki-energy, even though it is minute, could be multiplied enormously through the signal transduction network. In understanding $\mathrm{Ki}$ phenomena, the fact that a minute initial change could cause a tangible effect seems to be important. This is discussed in terms of the so-called 'Butterfly Effect' of a nonlinear chaotic system (41). Further study is needed to identify what enzyme or protein is the 'first receptor' of Ki-energy, and by what mechanism? These would be interesting but challenging questions.

We are still in an infant stage in understanding effects or roles of ' $\mathrm{Ki}$ ' in bone metabolism. Many more experiments must be performed before we could draw conclusions. For example, detailed time course study of Ki-exposure $(1,2,5,10 \mathrm{~min}$ or even longer) should be performed. We should also examine how much Nishino's students could influence bone cell culture with their $\mathrm{Ki}$-energy. If only one person can demonstrate Ki-power, then, it would be difficult to regard the Ki-phenomenon as science. Concerning this point, we are optimistic because we have evidence that both S.T. Ohnishi and T. Ohnishi were able to inhibit growth of cultured caner cells, even though their Ki-effects were not as strong as Nishino's (42). We presented the possibility that Ki-energy may contain infrared radiation $(26,27,42)$. Therefore, effect of the depth of culture medium should be examined because if Ki-energy contains infrared radiation, it may be absorbed by water. The effects of materials which may pass or block infrared radiation should also be examined. We performed some tests of this kind in our previous study $(26,27)$. We have a preliminary result to suggest that Ki-energy may have a peak wavelength in the near-infrared range. Based upon these results, we are proposing a possible mechanism for the generation and transmission of Ki-energy through air (submitted for publication).

In summary, in osteoblastic cell culture experiments with MC3T3-E1 cells, Ki-energy emitted from the fingers of a Japanese Ki expert increased the cell number during the proliferation stage. Ki-energy also stimulated the gene expressions related to bone mineralization during the differentiation stage of the same cells. In mouse bone marrow culture, Ki-energy decreased the formation of osteoclast-like cells. Although we do not know the mechanism by which Ki-energy stimulated these changes, all of our observations suggest that Ki-energy may have a potential to prevent osteoporosis. We hope our results will stimulate further investigation in this field.

\section{Acknowledgment}

We thank the two anonymous reviewers of our manuscript for their valuable suggestions. Thanks are also due to Mr. Tsutomu Saito for taking a picture [Fig. 1C] and for preparing supplemental data shown on the eCAM website, and to Mr Mark Singer for editorial assistance.

\section{References}

1. Nishimoto SK, Chang C-H, Gendler E, Stryker WF, Nimni ME. The effect of aging on bone formation in rats: biochemical and histological evidence for decreased bone formation capacity. Calcif Tissue Int 1985;37:617-24.

2. Shapira C, Slinn S, Sarid M, Mokadi S, Kabala A, Silbermann. Calcium and vitamin Denriched diets increase and preserve vertebral mineral content in aging laboratory rats. Bone $1995 ; 16: 575-82$.

3. Cooper C, Melton JI. Epidemiology of osteoporosis. Trends Endocrinol Metab 1995;3:224-9.

4. Wild RA, Buchamain JR, Meyers C, Demers LM. Declining adrenal androgen: an association with bone loss in aging women. Proc Soc Exp Biol Med 1987;186:335-60.

5. Riggs BL, Melton LJI. Osteoporosis: Etiology, Diagnosis, and Management., 2nd edn. Philadelphia, USA: Lipincott-Raven, 1995.

6. Schmitt IU, Walkley GK, Turner RT. Effects of estrogen and progesterone on tibia histomorphometry in growing rats. Calcif Tissue Int 2000;67:47-52.

7. Kalu DN. The ovariectomized rat model for postmenopusal bone loss. Bone Miner 199;15:175-92.

8. Nishida A, Ito M, Uetani M, Nakayama T, Tanaka T. Effect of etidronate on three-demensional trabecular structure in ovariectomized or sciatic neuretomized rats. $J$ Bone Miner Metab 2004;22:335-40.

9. Mochizuki K, Inoue T. Effect of salmon calcitonin on experimental osteoporosis induced by ovariectomy and low-calcium diet in the rat. J Bone Miner Metal 2000;18:194-207.

10. Moris HA, Need AG, Horowitz M, O'Leughlin PD, Nordin BEC. Calcium adsorption in normal and osteoporotic postmenopausal women. Calcif Tissue Int 1991;48:240-3.

11. Uchiyama Y, Higuchi Y, Takeda S, Masaki T, Shiraishi A, Sato K, et al. ED-71, a vitamin D analog, is a more potent inhibitor of bone 
resorption than alfacalcidol in an estrogen-defficient rat model of osteoporosis. Bone 2002;30:582-8.

12. Bonjour J-P, Schurch M-A, Rozzari R. Nutritional aspects of hip fractures. Bone 1996;18:1395-445.

13. Yamaguchi M. Isoflavone and bone metabolism: its cellular mechanism and preventive role in bone loss. J Health Sci 2002;48:209-22.

14. Uchiyama S, Yamaguchi M. Inhibitory effect of beta-cryptoxanthin on osteoclast-like cell formation in mouse marrow culture. Biochem Pharmacol 2004;67:1297-305.

15. Uchiyama S, Yamaguchi M. Beta-cryptoxanthin stimulates cell differentiation and mineralization in osteoblastic MC3t3-E1 cells. $J$ Cell Biochem 2005;95:1224-34.

16. Hidaka S, Uchiyama S, Nakatsuma A, Hashimoto K, Ohnishi ST, Yamaguchi M. Royal Jelly prevents osteoporosis in rats: beneficial effects in ovariectomy model and in bone tissue culture model. Evid-based Complement Altern Med 2006;3:339-48.

17. Hidaka S, Okamoto Y, Nakajima K, Suekawa M, Liu S-Y. Preventive effects of traditional Chinese (Kampo) medicines on exerimental osteoporosis induced by ovariectomy in rats. Calcif Tissue Int 1997;61:239-46.

18. Hidaka S, Okamoto Y, Yamada Y, Kon Y, Kimura T. A Japanese herbal medicine, Chujo-to, has a beneficial effect on the osteoporosis in rats. Phytother Res 1999;13:14-9.

19. Nishino K. The Breath of Life: using the Power of Ki for Maximum Vitality. Tokyo, New York, London: Kodansha International, 1997.

20. Nishino K. Le Souffle de Vie, Utiliser le Pouroir du Ki. Paris: Guy Tredaniel Editeur, 1998.

21. Nishino K. Il Respiro Della Vita, La massima vitalita dalla forza del $K i$, Esercizi di Respirazione facili, effieaci, completamente illustrati. Rome, Italy: Edizioni Mediterranee, Via Flaminia, 1999.

22. Nishino K. Ki-energy in health. Proceedings for the 4th International Congress on Traditional Asian Medicine 1994;1:148-70.

23. Nishino K. Nishino Breathing Method: Elevation of Self Energy (in Japanese). Tokyo: Gakushu Kenkyu Pub. Co., 2005.

24. Nishino K. The Nishino Breathing Method (in Japanese). In: Arita H (ed). The Dictionary of Respiration. Tokyo: Asakura Book Publishing Co., 2006, 678-97.

25. Kimura H, Nagao F, Tanaka Y, Sakai S, Ohnishi ST, Okumura K. Beneficial effects of the nishino breathing method on the immune activity and stress level. $J$ Altern Complement Med 2005;11:285-91.

26. Ohnishi ST, Ohnishi T, Nishino K, Tsurusaki Y, Yamaguchi M. Growth inhibition of cultured human carcinoma cells by Ki-energy (Life Energy): Scientific study of Ki-effect on cancer cells. Evid-based Complement Altern Med 2005;2:387-93.
27. Ohnishi ST, Ohnishi T, Nishino K. Ki- energy (life-energy) protects isolated mitochondria from oxidative injury. Evid-based Complement Altern Med 2006;3:475-82.

28. Kotaoka J. My body Laughes (in Japanese). In: Nishino K (ed). The Nishino Breathing Method: The power of Living and Seven Principles. Tokyo: Chikuma Shobo Publ.Co. 2003, 239-46.

29. Yumi K. Nishino K (ed). The Ultimate Example of Nishino Breating Method: everyday of yumi kaoru with slim and bouncing body (in japanese). TAKE Shobo Pub. Co., 2005.

30. Zaidi M, Blair HC, Moonga BS, Abe E, Huang C-H Osteoclastogenesis, bone resorption, and osteoclast-based therapeutics. J Bone Miner Res 2003;18:599-609.

31. Takahashi N, Yamana H, Yoshiki S, Roodman GD, Mundy GR, Jones SJ, et al. Osteoclast-like cell formation and its regulation by osteotropic hormones in mouse bone marrow cultures. Endocrinology 1988;122:1373-82.

32. Mundy GR, Roodman GD. Peck WA (ed). Osteoclast ontogeny and function. Amsterdam: Elsevier Science, 1987.

33. Burstone MS. Histochemical demonstration of acid phosphatases with naphthol AS-phosphates. J Natl Cancer Inst 1958;21:523-39.

34. Minkin C. Bone acid phosphatase as a marker of osteoclast function. Calcif Tissue Int 1982;34:285-90.

35. Chomczynski P, Sacchi N. Single-step method of RNA isolation by acid guanidinum thiocyanate-phenol-chloroform extraction. Anal Biochem 1987;162:156-9.

36. Sohn KY, Maity SN, de Crombrugghe B. Studies on the structure of CBF-A isoform generated from an alternatively spliced RNA. Gene 1994;139:147-53.

37. Seth A, Lee BK, Qi S, Vary CPH. Coordinate expression of novel genes during osteoblast differentiation. J Bone Miner Res 2000;15:1683-96.

38. Desbois C, Hogue DA, Karsenty G. The mouse osteocalcin gene culture contains three genes with two separate spatial and temporal patterns of expression. J Biol Chem 1994;269:1183-90.

39. Derynck R, Jarret JA, Chen EY, Goeddel DV. The murine transforming growth factor-beta precursor. $J$ Biol Chem 1986;261:4377-9.

40. Bell GI, Stempien MM, Fong NW, Rall LB. Sequences of liver cDNAs encoding two different mouse insulin-like growth factor I precursors. Nucleic Acids Res 1986;14:7873-82.

41. Ohnishi ST. Ki: a key to transform the century of death to the century of life. Evid-based Complement Altern Med 2007; doi:10.1093/ecam/nem021.

42. Ohnishi ST, Ohnishi T. The Nishino Breathing Method and Ki-energy (Life-energy): A Challenge to Traditional Scientific Thinking. Evid-based Complement Altern Med 2006;3:191-200.

Received October 17, 2006; accepted March 13, 2007 


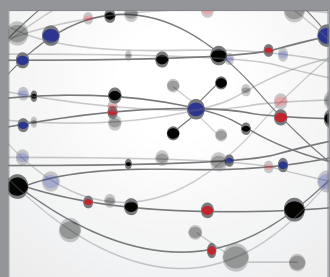

The Scientific World Journal
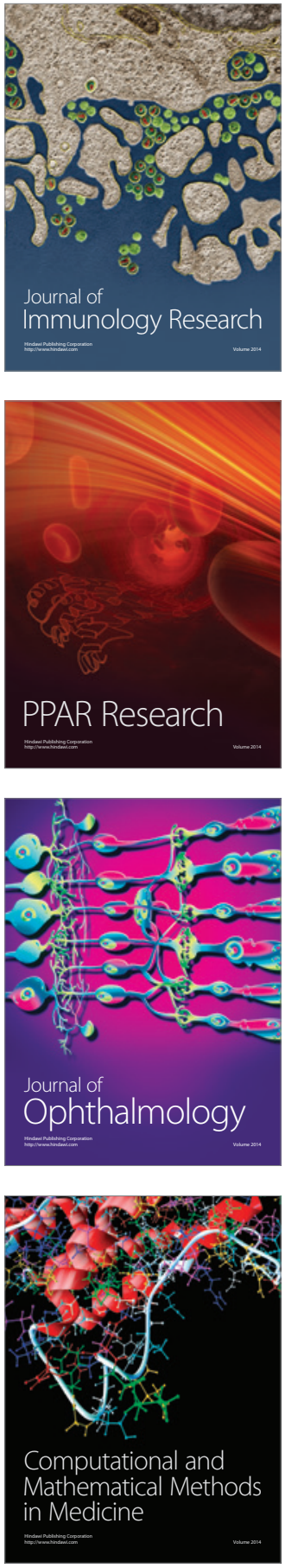

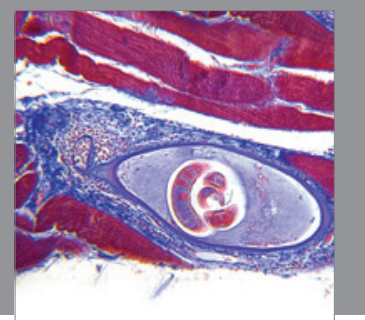

Gastroenterology

Research and Practice
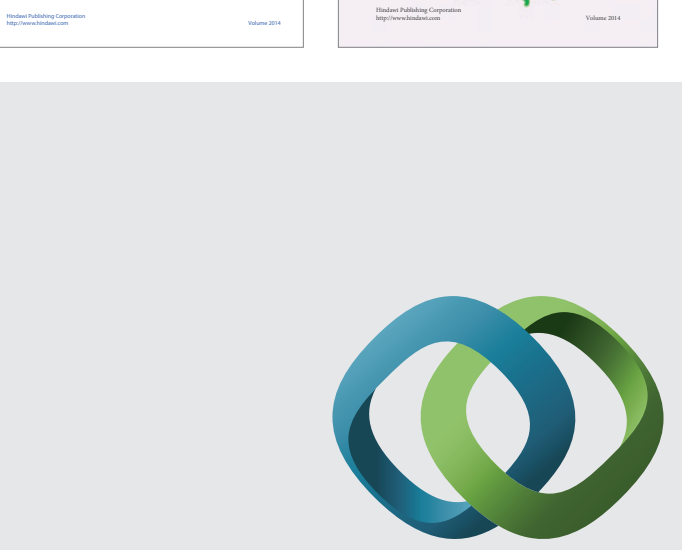

\section{Hindawi}

Submit your manuscripts at

http://www.hindawi.com
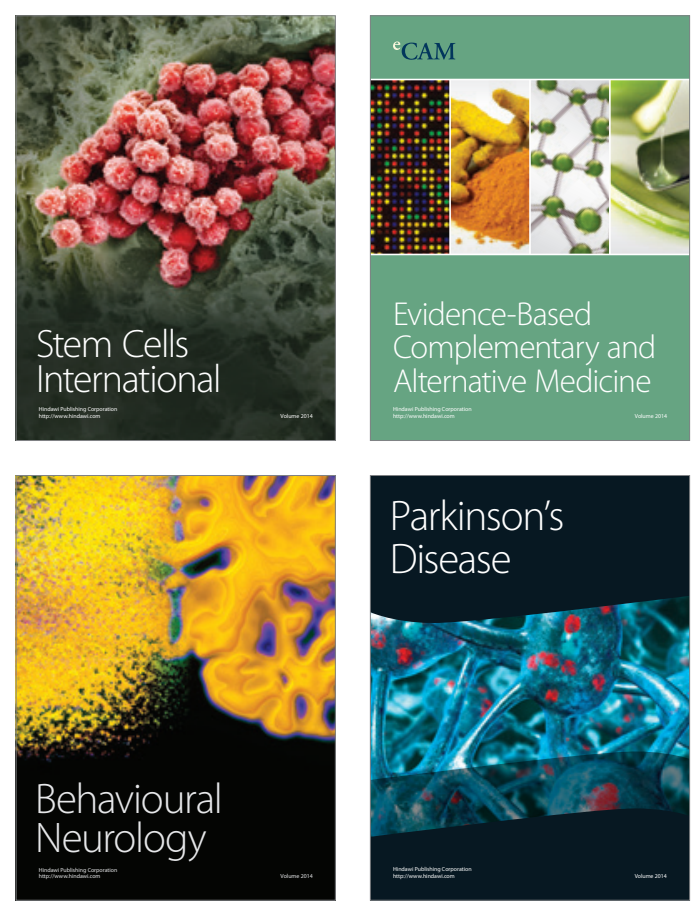

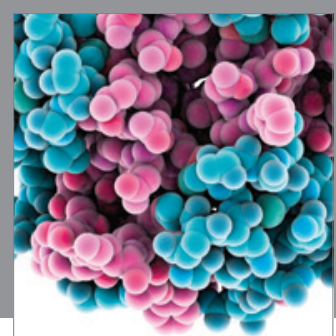

Journal of
Diabetes Research

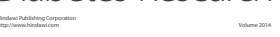

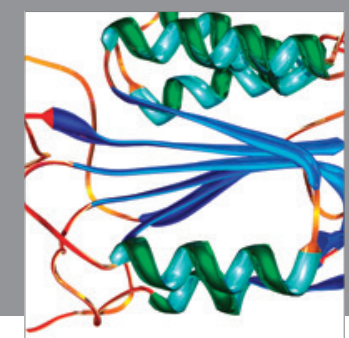

Disease Markers
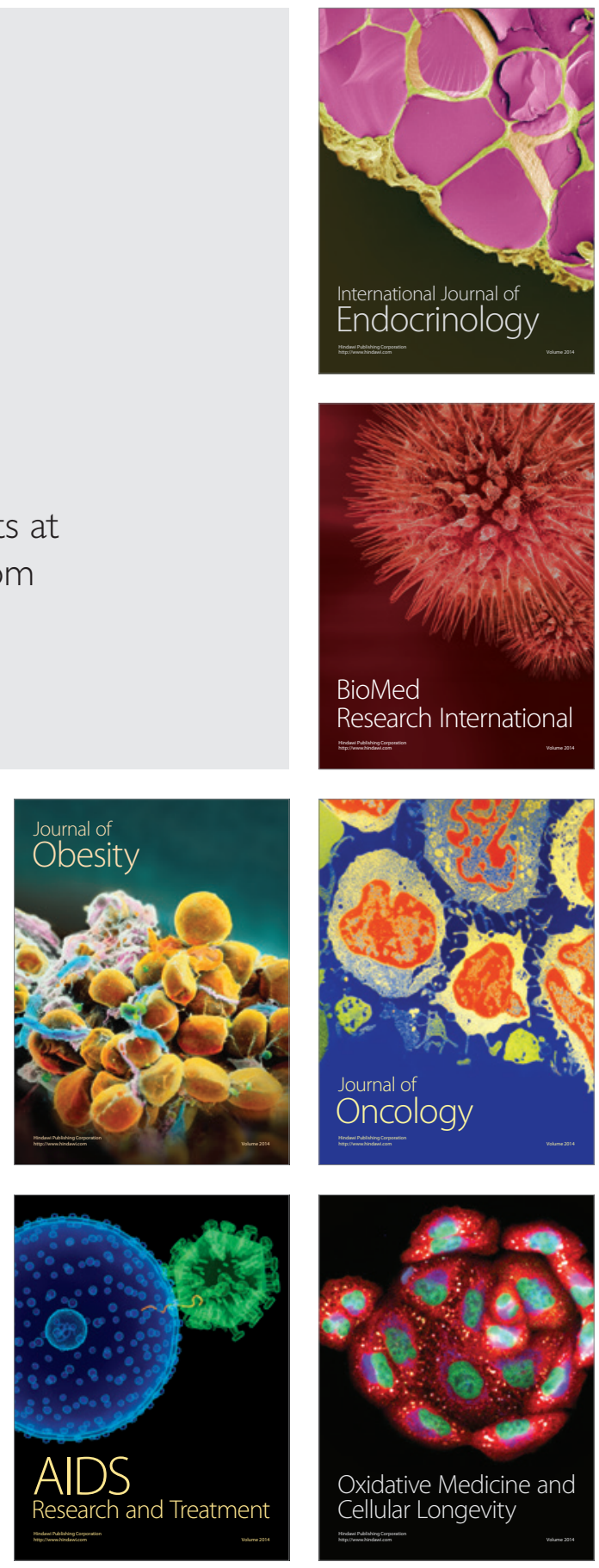